\title{
Intravenous pantoprazole: A new tool for acutely ill patients who require acid suppression
}

Eric F Trépanier BScPhm PharmD

EF Trépanier. Intravenous pantoprazole: A new tool for acutely ill patients who require acid suppression. Can J Gastroenterol 2000;14(Suppl D):11D-20D. Until now, oral proton pump inhibitors have not been available as parenteral therapy in the acute care setting. Pantoprazole is the first parenteral proton pump inhibitor to become available in Canada. This agent is superior to the parenteral histamine2 receptor antagonists with respect to acid suppressive effects and is not associated with tolerance development. Another advantage over the histaminez receptor antagonists is that pantoprazole does not require dosage adjustment in patients with renal impairment. Dosage adjustments are also not required for elderly patients or those with hepatic impairment when the drug is used at the usual dose for a limited period of time. Contrary to intravenous cimetidine and ranitidine, which have negative inotropic and chronotropic effects, intravenous pantoprazole is well tolerated and has no significant effect on heart rate, contractility or blood pressure. The lack of drug interactions for this agent also simplifies its use, especially in patients who may require multiple drugs during hospitalization. Parenteral pantoprazole is effective in the treatment of reflux esophagitis. It is also promising for the treatment of upper gastrointestinal bleeding and in the perioperative care of patients with Zollinger-Ellison syndrome, but further research in these areas is necessary. Once the patient is able to tolerate oral medications, parenteral therapy can be easily converted to oral therapy using an oral dose that was equivalent to the parenteral dose (ie, $40 \mathrm{mg}$ given intravenously is equivalent to $40 \mathrm{mg}$ given orally).

Key Words: Intravenous; Pantoprazole; Parenteral therapy; Proton pump inhibitor

\section{Le pantoprazole intraveineux : nouveau} médicament pour les cas aigus de suppression de l'acidité

RÉSUMÉ : Jusqu'à maintenant, les inhibiteurs de la pompe à protons en préparation orale n'existaient pas en préparation parentérale pour le traitement des cas aigus. Le pantoprazole est le premier inhibiteur de la pompe à protons en préparation parentérale offert au Canada. Il est supérieur aux inhibiteurs parentéraux des récepteurs $\mathrm{H}_{2}$ à l'histamine en ce qui concerne la suppression de l'acidité et n'est pas associé au phénomène de la tolérance. Autre avantage du pantoprazole sur ces derniers inhibiteurs, il n'est pas nécessaire de modifier la dose chez les patients atteints d'insuffisance rénale. Il en va de même chez les patients âgés et chez ceux qui souffrent

voir page suivante 
d'insuffisance hépatique si le médicament est utilisé aux doses usuelles pour une période limitée. Contrairement à la cimétidine et à la ranitidine administrées par voie intraveineuse, qui produisent des effets inotropes et chronotropes négatifs, le pantoprazole intraveineux est bien toléré et n'a pas d'effet sur la fréquence cardiaque, la contractilité du cœur ou la pression artérielle. L'absence d'interactions médicamenteuses en simplifie également l'utilisation, surtout chez les patients hospitalisés devant prendre plusieurs médicaments. Le pantoprazole administré par voie parentérale est efficace pour le traitement de l'oesophagite peptique; il s'avère également prometteur pour le traitement des hémorragies digestives hautes ainsi que dans les soins peropératoires du syndrome de Zollinger-Ellison, mais d'autres recherches s'imposent dans ces derniers contextes. Une fois que les patients sont en mesure de tolérer les médicaments par voie orale, le passage du traitement de la voie parentérale à la voie orale se fait facilement, les doses étant les mêmes dans les deux cas ( $40 \mathrm{mg}$ par voie intraveineuse équivalent à $40 \mathrm{mg}$ par voie orale).
$\mathrm{P}$ roton pump inhibitors (PPIs) are the most effective agents in the treatment of acid-related diseases (1-4). However, until now, no parenteral formulation has been available in Canada for use in patients who are acutely ill and unable to take oral medications. Although parenteral omeprazole is available on the European market, it is not available in North America. Intravenous pantoprazole has been available on the German market since January 1998 and has recently become available in Canada. This agent offers more options to clinicians trying to control acid production in hospitalized patients. It offers many advantages over the parenteral histamine 2 receptor antagonists $\left(\mathrm{H}_{2} \mathrm{RAs}\right)$, and may be particularly useful in treating patients with upper gastrointestinal bleeding and in the perioperative management of patients with Zollinger-Ellison syndrome (ZES). The available literature on intravenous pantoprazole in the following areas is reviewed: pharmacology, pharmacodynamics, pharmacokinetics, drug interactions, clinical trial data, adverse effects, dosage and administration, and comparison with parenteral $\mathrm{H}_{2} \mathrm{RAs}$. In areas where the literature on intravenous pantoprazole is limited, the relevant data on intravenous omeprazole are discussed to highlight the potential role of intravenous PPIs in that setting.

\section{SEARCH STRATEGY}

A comprehensive literature search was conducted to identify all relevant literature. MEDLINE, EMBASE/Excerpta Medica and International Pharmaceutical Abstracts were searched. Bibliographies from retrieved articles were also scanned as necessary to identify articles that were not detected by other methods. Conference proceedings from the American Gastroenterology Association published from 1994 to 2000 were also searched to identify relevant abstracts. Finally, manufacturers of parenteral acid suppressive agents were contacted to obtain any unpublished data that would be appropriate for inclusion in the review.

\section{PHARMACOLOGY}

PPIs are substituted benzimidazoles that suppress gastric acid by affecting the final common pathway in acid production. They are weak bases that must be converted by acid to the active sulfenamide form before acting on the proton pumps $(1,5)$. The sulfenamide is a highly reactive compound that is capable of forming covalent bonds with cysteine residues on the proton pump (6). Because these are formed in the extra- cellular space, they can only react with proton pumps that are actively secreting acid within the canalicular space (6). They have no effect on pumps within the tubulovesicles of the intracellular space. Pantoprazole is relatively stable at moderately low pH values (ie, pH higher than 3.0$)(7,8)$. Therefore, the drug is activated only after it has penetrated relatively deeply into the proton pump, where the $\mathrm{pH}$ is less than 3.0. Consequently, it binds only to cysteine groups that are present in this area on the enzymes Cys-813 and Cys-822 (9).

\section{PHARMACODYNAMICS}

Intravenous pantoprazole is a potent acid suppressive agent. Actively secreting pumps are inhibited on initial exposure to the drug, resulting in immediate acid suppression. Its effect on gastric $\mathrm{pH}$ is substantial with the initial dose and increases with repeated dosing as the drug binds to other secreting proton pumps until a steady-state is reached after three to five days with once-daily dosing $(1,10)$. A doseranging study of intravenous pantoprazole in 12 healthy volunteers demonstrated that $60 \mathrm{mg}$ and $80 \mathrm{mg}$ doses achieved almost complete inhibition of acid output (11). The drug is most effective when more proton pumps are actively secreting acid, such as in the setting of pentagastrin stimulation (12). A baseline $\mathrm{pH}$ of 1.7 in healthy volunteers was increased to 2.8 with intravenous pantoprazole alone and 3.9 with the combination of intravenous pantoprazole and pentagastrin (12). In this setting, a single dose of 80 or $120 \mathrm{mg}$ of intravenous pantoprazole controlled acid output for longer than $20 \mathrm{~h}$, which was significantly longer than that of intravenous famotidine (6.5 h) (13).

Various dosage regimens have been tested in healthy volunteers. Trials comparing intravenous pantoprazole $40 \mathrm{mg}$ with oral pantoprazole $40 \mathrm{mg}$ demonstrated that each dose produced similar effects on acid output $(14,15)$. A dose of $40 \mathrm{mg}$ administered orally resulted in a median $\mathrm{pH}$ of 3.1 , while the same dose administered intravenously produced a median $\mathrm{pH}$ of 3.3 in a group of healthy volunteers with a baseline $\mathrm{pH}$ of $1.4(14,15)$. This feature facilitates dosage conversion from intravenous to oral therapy in the acute care setting; $40 \mathrm{mg}$ taken intravenously is equivalent to $40 \mathrm{mg}$ taken orally. A study conducted in patients with gastroesophageal reflux disease (GERD) also found that doses of $20 \mathrm{mg}$ and $40 \mathrm{mg}$ taken orally reduced the maximal acid output to a similar extent as the same doses given intravenously (16). 
An abstract presented at Digestive Disease Week, May 2000, reported the acid inhibitory efficacy of intravenous pantoprazole $(40 \mathrm{mg}$ ) compared with that of lansoprazole (30 mg) administered via nasogastric tube in 33 healthy volunteers (17). Although the results suggested that nasogastric lansoprazole results in superior $\mathrm{pH}$ control, the study design had certain limitations. First, breakfast was served $1 \mathrm{~h}$ after drug administration. This corresponds with the maximum serum concentration $\left(\mathrm{C}_{\max }\right)$ of oral lansoprazole $(18)$, which means that the maximum amount of drug is available to inhibit the actively secreting proton pumps. On the contrary, the $\mathrm{C}_{\max }$ for intravenous pantoprazole is at the end of the infusion, and with a half-life of roughly $1 \mathrm{~h}$, only about $50 \%$ of the original dose would be available for proton pump inhibition when breakfast was served. Second, a recent study indicated that lansoprazole pharmacokinetics in GERD patients differ from those in healthy volunteers (18). Extrapolation of these results to patients in the intensive care unit (or others) is, therefore, questionable. Further research is required before definitive conclusions can be made about nasogastric administration of lansoprazole compared with intravenous administration of pantoprazole.

Another study evaluated the impact of four intravenous pantoprazole dosage regimens on gastric $\mathrm{pH}$ in healthy volunteers (19). The regimens were as follows: $40 \mathrm{mg}$ bolus every $8 \mathrm{~h}$; $40 \mathrm{mg}$ bolus followed by infusion of $4 \mathrm{mg} / \mathrm{h} ; 80 \mathrm{mg}$ bolus over $2 \mathrm{~h}$ with $8 \mathrm{mg} / \mathrm{h}$ continuous infusion (ie, $48 \mathrm{mg} / \mathrm{h}$ for the first $2 \mathrm{~h}$ ); $80 \mathrm{mg}$ bolus over $2 \mathrm{~min}$ followed by infusion of $8 \mathrm{mg} / \mathrm{h}$; and placebo. Table 1 summarizes the results of this study. More than $80 \%$ of a $24 \mathrm{~h}$ period was spent above a $\mathrm{pH}$ of 6.0 using an infusion of $8 \mathrm{mg} / \mathrm{h}$ preceded by an $80 \mathrm{mg}$ bolus.

A separate study reported the effect of an $80 \mathrm{mg}$ loading dose followed by a continuous infusion of $6 \mathrm{mg} / \mathrm{h}$ for $72 \mathrm{~h}$ in patients with bleeding peptic ulcer (Forrest Ia, Ib or IIa) (20). During the first $48 \mathrm{~h}$ of infusion, this regimen resulted in a median $\mathrm{pH}$ of 5.9 , with a $\mathrm{pH}$ higher than 5 for $77 \%$ of the interval, and a $\mathrm{pH}$ higher than 6 for $47 \%$ of the interval (20). In another study, the $80 \mathrm{mg}$ bolus plus $8 \mathrm{mg} / \mathrm{h}$ infusion regimen was also tested in patients with bleeding peptic ulcer. Using this dose, the gastric $\mathrm{pH}$ was maintained above 5.0 for $89 \%$ of the first $24 \mathrm{~h}$ monitoring period, for $91 \%$ of the second $24 \mathrm{~h}$ period (ie, 24 to $48 \mathrm{~h}$ ) and for $90 \%$ of the total $48 \mathrm{~h}$ monitoring period (21). This regimen, therefore, appears to be best suited for the treatment of patients with gastrointestinal bleeding.

\section{PHARMACOKINETICS}

When administered orally, pantoprazole is well absorbed from the gastrointestinal tract, with a bioavailability of approximately $77 \%$ (95\% CI, $67 \%$ to $89 \%$ )(22), which is unaffected by cotreatment with antacids $(23)$ or food $(8,24)$. Its apparent volume of distribution is $0.15 \mathrm{~L} / \mathrm{kg}(22,25)$. The drug is highly protein bound at $98 \%$ (22). Almost $80 \%$ of an oral or intravenous dose is excreted as metabolites in the urine; the remainder is found in feces and originates primarily from biliary secretion $(25,26)$. The drug's clearance is approximately $0.13 \mathrm{~L} / \mathrm{h} / \mathrm{kg}$ (range 0.055 to $0.196 \mathrm{~L} / \mathrm{h} / \mathrm{kg}$ ) (22)
TABLE 1

Summary of the effect of four pantoprazole dosing regimens on the median percentage time above $\mathrm{pH} 3.0,4.0,5.0$ and 6.0 over a $24 \mathrm{~h}$ period

\begin{tabular}{lcccc}
\hline & \multicolumn{4}{c}{ Percentage time above pH } \\
Treatment & pH 3.0 & $\mathbf{p H ~ 4 . 0}$ & $\mathbf{p H ~ 5 . 0}$ & $\mathbf{p H ~ 6 . 0}$ \\
\hline Placebo & 22 & 7 & 1 & 1 \\
$40 \mathrm{mg} \mathrm{q} 8 \mathrm{~h}$ & 49 & 20 & 5 & 0 \\
$40 \mathrm{mg}$, then $4 \mathrm{mg} / \mathrm{h}$ & 88 & 54 & 24 & 13 \\
$48 \mathrm{mg} / \mathrm{h}$ for $2 \mathrm{~h}$, & 94 & 82 & 55 & 31 \\
$\quad$ then $8 \mathrm{mg} / \mathrm{h}$ & & & & \\
$80 \mathrm{mg}$, then $8 \mathrm{mg} / \mathrm{h}$ & 99 & 99 & 94 & 84 \\
\hline
\end{tabular}

q8h Every $8 \mathrm{~h}$. Data from reference 19

and is not dose dependent. Pantoprazole has a plasma halflife of approximately $1.1 \mathrm{~h}$ (range 0.8 to $2.9 \mathrm{~h}$ ) (22). Despite its short half-life, pantoprazole's antisecretory effect persists over $24 \mathrm{~h}$ after dosing because of the covalent binding of the activated drug to the proton pump in the parietal cell $(11,27)$.

The area under the concentration-time curve (AUC) and the $\mathrm{C}_{\max }$ increase in proportion with the dose, up to $240 \mathrm{mg}$ taken intravenously and $120 \mathrm{mg}$ taken orally, indicating linear pharmacokinetics $(26,28-30)$. Pantoprazole is extensively metabolized in the liver. Its main metabolite arises from $\mathrm{O}$-demethylation and conjugation with sulphate, rather than oxidation (31). Because of its metabolic pathway, pantoprazole has a low potential for drug interactions mediated by the cytochrome P450 (CYP450) system $(26,31-33)$.

\section{SPECIAL POPULATIONS}

Pantoprazole is metabolized in the liver, but its inactive metabolites are excreted renally. When it was administered to patients with severe renal impairment, defined as creatinine clearance less than $20 \mathrm{~mL} / \mathrm{min}$, no significant differences in pantoprazole concentrations were noted between these patients and healthy control patients (34). Hemodialysis also did not affect pharmacokinetic parameters of pantoprazole or its main metabolite in patients with stable renal disease (25) or end-stage renal failure (35). Therefore, no dose adjustments are necessary for patients with renal impairment or those on hemodialysis (34).

In patients with hepatic cirrhosis, clearance is decreased by about fivefold and $\mathrm{C}_{\max }$ is increased by a factor of $1.5 \mathrm{com}$ pared with that of healthy volunteers $(25,36,37)$. However, volume of distribution and bioavailability remain constant. Consequently, the AUC increased by a factor of three to seven, and the half-life increased to 6 to $9 \mathrm{~h}(25,36,37)$. Despite these changes, dose adjustment is probably not necessary on the basis of the drug's safety and tolerability, and the fact that its serum concentrations do not increase further after the second dose. These data support the use of pantoprazole when given at usual therapeutic doses for a limited period of time in patients with mild to moderate hepatic cirrhosis.

A small subpopulation (approximately $2 \%$ to $3 \%$ of white 
people, probable cosegregation with CYP2C19 deficiency) appears to be poor metabolizers of pantoprazole and other PPIs with pharmacokinetic characteristics similar to those found in patients with liver cirrhosis. In these patients, pantoprazole clearance is lower, at approximately $0.027 \mathrm{~L} / \mathrm{h} / \mathrm{kg}$, with a reflected increase in the half-life to 5.1 to $8.7 \mathrm{~h}$ $(22,28)$.

The pharmacokinetic parameters of pantoprazole in elderly subjects were not significantly different from those of young healthy volunteers (38). At steady-state, the AUC and $\mathrm{C}_{\max }$ increase by $35 \%$ and $22 \%$, respectively (38). These changes are not clinically significant, and pantoprazole can be safely administered to elderly patients without dosage adjustment $(30,38)$.

\section{DRUG INTERACTIONS}

No drug interactions mediated by the cytochrome P450 enzyme system have been documented with pantoprazole. Various studies assessed the risk for interactions with drugs that are metabolized through all major metabolic pathways in humans. None demonstrated any clinically significant drug interactions. Drugs that were studied in combination with pantoprazole include ethanol (39), antipyrine (40), diazepam (41), diclofenac (42), carbamazepine (43), naproxen (44), cisapride (45), glibenclamide (46), digoxin (47), metoprolol (48), nifedipine (49), cyclosporine (50), phenytoin $(51)$, caffeine $(52,53)$, theophylline $(54-56)$, phenprocoumon (57), warfarin (58), tacrolimus (59) and piroxicam (60).

The risk exists, however, for the pantoprazole-induced increase in gastric $\mathrm{pH}$ to cause changes in drug absorption. This has been studied with digoxin (47) and nifedipine (49). No clinically relevant changes in bioavailability of either agent were noted. However, the azole antifungal agents ketoconazole and itraconazole require an acidic medium for absorption from the gastrointestinal tract (61-63). A reduction in azole bioavailability when it is co-administered with $\mathrm{H}_{2} \mathrm{RAs}$ or PPIs has been documented $(62,64,65)$. The potential risk of antifungal therapeutic failure associated with this combination warrants the use of alternative antifungal agents or alternative routes of administration (ie, parenteral azole) where possible (66). Alternatively, consumption of a cola beverage along with the azole may eliminate the problem by temporarily raising intragastric $\mathrm{pH}$ and facilitating drug absorption $(61,67,68)$.

\section{CLINICAL TRIAL DATA}

Reflux esophagitis: Three published studies have evaluated the use of intravenous pantoprazole in the treatment of reflux esophagitis (69-71). The first was a randomized, double-blind comparative study of the following pantoprazole regimens in the treatment of 45 patients with symptomatic Savary-Miller grades II and III reflux esophagitis: intravenous pantoprazole $40 \mathrm{mg}$ once daily for five days, which was then switched to oral therapy for the subsequent three to seven weeks (intravenous/oral regimen); and exclusively oral pantoprazole $40 \mathrm{mg}$ once daily for four to eight weeks (71). Symptom scores were markedly improved within three days of treatment initiation, and over $90 \%$ of symptoms were resolved after four weeks of therapy with intravenous/oral pantoprazole or oral pantoprazole. At eight weeks, healing rates above $85 \%$ were achieved in both groups. Both treatment regimens were, therefore, equally effective in the treatment of symptomatic grades II and III reflux esophagitis.

Two other prospective noncomparative studies assessed the efficacy and safety of the intravenous/oral dosing regimen in patients with grades II and III reflux esophagitis $(70,71)$. One study was conducted at 14 centres in Germany (70), while the other was conducted at 10 centres in Austria (71). Endoscopic evaluations were performed at four and eight weeks to assess esophageal status. In the German study, the four- and eight-week healing rates were 114 of 142 (80\%; $95 \%$ CI $73 \%$ to $86 \%)$ and 132 of 142 (93\%; $95 \%$ CI $87 \%$ to $97 \%)$, respectively (70). Corresponding healing rates in the Austrian study were 85 of 98 (87\%; $95 \%$ CI $78 \%$ to $93 \%$ ) and 93 of 98 (95\%; 95\% CI 88\% to 98\%) at four and eight weeks, respectively. Symptoms of reflux esophagitis were markedly reduced after three to four days of intravenous/oral therapy in both studies. After two weeks, symptoms (ie, heartburn, acid eructation and pain on swallowing) were eliminated in $87 \%$ or more of patients in both studies. In the German study, healing rates were similar to those obtained in studies that evaluated patients who were treated exclusively with oral pantoprazole (70). The results of these studies further support the efficacy of the intravenous/oral pantoprazole regimen in healing and resolving symptoms associated with reflux esophagitis.

Another study compared antacid use for patients receiving oral pantoprazole who were switched to either intravenous placebo or intravenous pantoprazole (72). The authors found that the percentage of patients who used antacids for symptom relief was significantly less in the intravenous pantoprazole group than in the intravenous placebo group (72).

Gastrointestinal hemorrhage: Acute upper gastrointestinal bleeding accounts for 25 to 150 hospital admissions per 100,000 residents each year $(73,74)$. Mortality associated with this condition ranges from $10 \%$ to $15 \%$ (73-78). Patients who are actively bleeding or at high risk for bleeding (ie, those with a visible vessel or vessel capped with fresh thrombus) at the time of admission are generally treated with endoscopic therapy $(73,79)$. Low gastric $\mathrm{pH}$ has been shown to impair platelet function and coagulation $(73,80$ 82). Optimal hemostasis is achieved when the $\mathrm{pH}$ is around 7.0 (81). Once the $\mathrm{pH}$ decreases below 6.8, coagulation becomes abnormal, and further decreases result in more pronounced impairment (73,80-82). Patients with bleeding ulcers have also been found to have significantly more acid production than patients with nonbleeding ulcers (83). Therefore, using drug therapy to increase the $\mathrm{pH}$ toward 7.0 should theoretically improve coagulation and platelet function, thereby facilitating healing.

The first acid suppressive agents to be used in this setting were the $\mathrm{H}_{2}$ RAs. A meta-analysis of 27 trials using $\mathrm{H}_{2} \mathrm{RA}$ 
therapy in patients with acute gastrointestinal bleeding reported a decrease in rebleeding rates (by 32\%), requirements for surgery (by 39\%) and mortality (by 47\%) (84). Although these results were promising for the use of $\mathrm{H}_{2} \mathrm{RAs}$, Walt et al (85) later published a large prospective, randomized, placebo controlled study of intravenous famotidine that failed to support these findings. This well designed trial comprising 1005 patients reported no significant differences in rebleeding rates, surgical requirements and mortality between famotidine and placebo (85). Potential explanations for the $\mathrm{H}_{2}$ RA's lack of efficacy in this setting include their minimal effects on acid stimulated by gastrin or acetylcholine (86), and the development of tolerance to their acid suppressive effects, even during short term use (87-91). Because PPIs are more potent inhibitors of acid suppression and have not been associated with tolerance, they may be expected to provide an incremental benefit over the $\mathrm{H}_{2}$ RAs.

Studies examining the use of intravenous omeprazole doses have had mixed results $(75,89,92-104)$. However, many of these trials used omeprazole dosing regimens that are thought to be suboptimal and will not be discussed further $(75,89,93-95,97,100)$. Three other randomized, controlled trials assessed the use of higher doses of omeprazole, namely an $80 \mathrm{mg}$ bolus followed by 6.7 to $8 \mathrm{mg} / \mathrm{h}$ continuous infusion in the treatment of high risk patients with either actively bleeding ulcers or nonbleeding visible vessels $(96,98,99)$. Previously published studies demonstrated that these dosing regimens achieved an intragastric $\mathrm{pH}$ of greater than 6.0 for more than $80 \%$ of a $24 \mathrm{~h}$ period, with a median $24 \mathrm{~h} \mathrm{pH}$ of 6.5 to $7.5(90,105,106)$. In two of these three well designed studies, therapy was administered in a double-blind fashion $(98,99)$, while in the third study, the attending physicians and surgeons were aware of the treatment given in each case (96). Two of the trials were placebo controlled $(98,99)$, and the other compared the PPI with cimetidine (300 mg intravenous bolus followed by $1200 \mathrm{mg} /$ day infusion for three days, then $400 \mathrm{mg}$ given orally twice daily) (96). Endoscopic therapy was performed for actively bleeding ulcers in all three studies before beginning omeprazole therapy. Two of the studies used an overall outcome scale based on clinical status and laboratory findings $(98,99)$, while two reported more traditional outcome measures such as need for transfusion, surgery and mortality $(96,98)$. In the trial by Schaffalitzky et al (99), the overall outcome scale was improved significantly more with omeprazole than with placebo $(\mathrm{P}=0.004)$. In the other two trials, omeprazole therapy resulted in a significant reduction in rebleeding rates at days 3,14 and $21(96,98)$. The requirements for surgery and mortality rates were not significantly different from those for cimetidine in one study (96). The other placebo controlled trial showed a significant reduction in surgical requirements but an unexplained increase in 21-day mortality rates with omeprazole therapy. These studies indicate that parenteral omeprazole reduces the need for transfusion and possibly requirements for surgery in patients with acute upper gastrointestinal bleeding.

Data are emerging on the use of intravenous pantoprazole in patients with gastrointestinal bleeding. Pharmacodynamic studies have shown that the administration of intravenous pantoprazole using an $80 \mathrm{mg}$ bolus followed by an infusion of $8 \mathrm{mg} / \mathrm{h}$ results in $\mathrm{pH}$ changes that are similar to those obtained with the same dosing regimen of omeprazole. The resulting $\mathrm{pH}$ values are greater than 6.0 for $64 \%$ to $84 \%$ of a $24 \mathrm{~h}$ period in healthy volunteers (19) and in patients with acute gastrointestinal bleeding (21).

Two clinical trials presented at Digestive Disease Week in May 1999 reported the use of intravenous pantoprazole in patients with gastrointestinal bleeding. The first trial was an open-label pilot study that compared two different regimens of pantoprazole in 168 patients with Forrest Ia, Ib or IIa peptic ulcer bleeding initially treated with endoscopic hemostasis (107). Pantoprazole was administered for three days $40 \mathrm{mg}$ intravenously once daily (low dose) or $40 \mathrm{mg}$ bolus followed by a continuous infusion of $8 \mathrm{mg} / \mathrm{h}$ (high dose). The $72 \mathrm{~h}$ rebleeding rates were $12 \%$ in the low dose group and $13 \%$ in the high dose group (not significant). The need for blood transfusions over $72 \mathrm{~h}$ was also similar between the groups, and the mortality rate at 14 days was approximately $2.5 \%$ in each group. The authors concluded that a dose of $40 \mathrm{mg}$ given intravenously once daily may be as effective as the high dose regimen in patients with gastrointestinal bleeding. However, based on the data presented above, it appears that a subtherapeutic dose of pantoprazole (ie, $40 \mathrm{mg}$ bolus instead of $80 \mathrm{mg}$ ) was used in this study, and the sample size may not have been adequate to detect a significant difference between the groups. Also, because the study was only presented in abstract form, details are not available and firm conclusions cannot be drawn from the available information. Therefore, further research, with the appropriate pantoprazole dosing regimen (ie, $80 \mathrm{mg}$ bolus, then $8 \mathrm{mg} / \mathrm{h}$ continuous infusion) (103), is necessary to determine its true impact on patients with gastrointestinal bleeding.

The second study compared two days of treatment with intravenous pantoprazole ( $40 \mathrm{mg}$ bolus followed by a continuous infusion of $8 \mathrm{mg} / \mathrm{h}$ ) with two days of treatment with intravenous ranitidine ( $50 \mathrm{mg}$ bolus followed by $12.5 \mathrm{mg} / \mathrm{h}$ continuous infusion) in 133 patients with Forrest Ia, Ib, Ila and $\mathrm{IIb}$ gastrointestinal bleeding in a randomized, open, parallel-group study (108). The $48 \mathrm{~h}$ rebleeding rates were $10 \%$ (six of 61 ) and $17 \%$ (10 of 58) in the pantoprazole and ranitidine groups, respectively (Cochran-Mantel-Haenszel test - not significant). The mortality rate at 10 days was $1.5 \%$ in each group. Although definite conclusions cannot be made without having access to the full report, these data indicate that pantoprazole may be superior to ranitidine in the prevention of peptic ulcer rebleeding (108).

More large scale, randomized, prospective studies of intravenous pantoprazole (especially $80 \mathrm{mg}$ bolus followed by $8 \mathrm{mg} / \mathrm{h}$ continuous infusion) in this setting are required to assess further its impact on clinical end points. However, based on the preliminary abstract data available for pantoprazole and the similar pharmacodynamic profiles of intravenous omeprazole and intravenous pantoprazole, par- 
enteral formulations of these PPIs are likely to have similar efficacies in this setting.

\section{ZES}

ZES is a condition that results in excessive acid secretion secondary to hypergastrinemia (109). Potent acid suppression is important in the prevention of complications such as ulceration, gastrointestinal bleeding and perforation (109). Although $\mathrm{H}_{2} \mathrm{RAs}$ have been useful in this setting, the PPIs are the drugs of choice because of their more potent acid suppression $(109,110)$. Parenteral acid suppression is essential when these patients undergo surgical procedures. Although $\mathrm{H}_{2} \mathrm{RAs}$ have been used successfully in this setting, they must be administered as continuous infusions, require frequent dosage adjustments and lose their efficacy over time $(111,112)$.

Two studies of intravenous omeprazole in the treatment of ZES have been published $(113,114)$. The first is a crossover pharmacokinetic study of $80 \mathrm{mg}$ oral and $40 \mathrm{mg}$ intravenous omeprazole in nine patients with ZES (113). The pharmacokinetic parameters of omeprazole in ZES patients were not different from those in healthy volunteers, except for the half-life, which was longer than that observed in healthy volunteers. Because five of the nine patients studied had gastric acid output exceeding the value for safe control (ie, greater than $10 \mathrm{mmol} / \mathrm{h}$ ) $24 \mathrm{~h}$ after intravenous omeprazole dosing, the investigators recommended using an omeprazole dose of $40 \mathrm{mg}$ given intravenously every $12 \mathrm{~h}$ (113).

A prospective study was conducted to assess the efficacy and safety of intravenous omeprazole in 20 patients with ZES who were undergoing surgery (114). In 19 of the 20 patients, acid output was well controlled with $60 \mathrm{mg}$ omeprazole administered as intravenous boluses every $12 \mathrm{~h}$. One patient required an increase to $100 \mathrm{mg}$ taken intravenously every $12 \mathrm{~h}$ to achieve control, defined as an acid output of less than $5 \mathrm{mmol} / \mathrm{h}$. The drug was well tolerated, and no patient experienced toxicity that could be attributed to the drug.

Patients with ZES have been effectively treated with oral pantoprazole (115-117). However, to establish a starting dose for intravenous pantoprazole in patients with ZES, a dose-ranging study was conducted in healthy volunteers who underwent pentagastrin stimulation to produce a hypersecretory state (13). The 39 subjects were administered single doses of pantoprazole 20, 40, 80 and $120 \mathrm{mg}$, famotidine $20 \mathrm{mg}$ or saline placebo in this open-label study. All pantoprazole doses resulted in a dose-dependent suppression of acid output to less than $10 \mathrm{mmol} / \mathrm{h}$ and had a longer duration of action than that of intravenous famotidine. Pantoprazole doses of 80 and $120 \mathrm{mg}$ had an onset of action of less than $1 \mathrm{~h}$ and suppressed acid output to less than $10 \mathrm{mmol} / \mathrm{h}$ for more than $20 \mathrm{~h}$ (13). The authors suggested, based on these results, that a dose of $80 \mathrm{mg}$ would rapidly and effectively control acid secretion in most patients with ZES (13).

A recent study evaluated the efficacy and safety of intravenous pantoprazole ( 80 to $120 \mathrm{mg}$ every 8 to $12 \mathrm{~h}$ ) in controlling acid output in 21 patients with ZES (118). Mean basal acid output in the absence of therapy was $40.2 \mathrm{mmol} / \mathrm{h}$. After an initial dose of $80 \mathrm{mg}$, acid output was controlled within the first hour in all patients. A dose of $80 \mathrm{mg}$ every $12 \mathrm{~h}$ was effective in 17 of the 21 (81\%) patients for up to seven days. Daily doses of $240 \mathrm{mg}$ controlled acid output in all remaining patients.

Another study reported the switch from oral PPI to intravenous pantoprazole in 14 ZES patients (119). The starting dose of intravenous pantoprazole was $80 \mathrm{mg}$ twice daily for seven days. This dose controlled acid output in 13 of the 14 patients for the duration of the study and appears to be the appropriate starting dose for these patients. The last patient who had been receiving omeprazole $100 \mathrm{mg}$ orally twice daily required an intravenous pantoprazole dose of $120 \mathrm{mg}$ twice daily to adequately control their disease (119).

Parenteral PPIs are the drugs of choice for controlling acid output in patients with ZES undergoing surgery. Intravenous pantoprazole provides significant advantages over $\mathrm{H}_{2} \mathrm{RAs}$ for rapid and effective control of acid output in ZES patients who cannot take oral agents (118). Compared with parenteral $\mathrm{H}_{2} \mathrm{RAs}$, they require minimal dosage adjustments, maintain their potency over time and do not require continuous infusion dosing.

\section{ADVERSE EFFECTS}

Intravenous pantoprazole was very well tolerated in clinical trials, with daily doses as high as $272 \mathrm{mg}(19,21,41)$. The two most common side effects were headache $(0.7 \%)$ and diarrhea $(0.3 \%)$. Other less common side effects include thrombophlebitis at the site of injection and other gastrointestinal disturbances such as flatulence, nausea and cramps. In a descriptive study of 269 patients who received intravenous pantoprazole in 17 European centres, the tolerability was assessed to be 'good' or 'very good' in $98 \%$ of patients (120). Only two unwanted drug reactions occurred, and their relations to drug intake were assessed to be unlikely (120).

Clinical laboratory results obtained in clinical trials did not reveal any clinically important changes during pantoprazole therapy. The only exception was the expected rise in serum gastrin secondary to gastric acid inhibition.

\section{DOSAGE AND ADMINISTRATION}

Intravenous pantoprazole is available as a $40 \mathrm{mg}$ vial of lyophilized powder, which must be reconstituted with $10 \mathrm{~mL}$ of normal saline. The resulting solution may be administered as a bolus injection, or diluted in $100 \mathrm{~mL}$ of normal saline or dextrose solutions for administration as a short term infusion or continuous infusion.

The usual dose of intravenous pantoprazole for the treatment of erosive esophagitis is $40 \mathrm{mg}$ given intravenously once daily. Once the patient is able to tolerate oral administration, the drug may be given at the same dose using the enteric-coated oral tablet. Conversion from intravenous to oral pantoprazole is one to one (15). An $80 \mathrm{mg}$ bolus followed by a continuous infusion of $8 \mathrm{mg} / \mathrm{h}$ provides optimal $\mathrm{pH}$ control for patients with acute upper gastrointestinal bleeding $(19,21)$. No dosing modifications are necessary for 


\section{COPYRIGHT PULSUS GROUP INC, DO NOT COPY}

TABLE 2

Summary of pharmacokinetic parameters of parenteral acid suppressive agents

\begin{tabular}{|c|c|c|c|c|}
\hline & Pantoprazole & Cimetidine & Ranitidine & Famotidine \\
\hline Dose linearity & Linear (intravenous/oral) & $\mathrm{N} / \mathrm{A}$ & $\mathrm{N} / \mathrm{A}$ & $\mathrm{N} / \mathrm{A}$ \\
\hline Oral bioavailability (\%) & 77 & $60-70$ & $50-60$ & $65-70$ \\
\hline Fraction excreted unchanged (\%) & Negligible & 75 & 70 & $65-70$ \\
\hline Plasma half-life (h) & $0.7-1.4$ & $1.5-2.3$ & $2.5-3.0$ & $2.5-3.5$ \\
\hline Protein binding & 98 & $13-26$ & 15 & 16 \\
\hline \multicolumn{5}{|l|}{ Hepatic impairment } \\
\hline Changes & $\mathrm{CL}$ decreased; $\mathrm{t}_{1 / 2}$ increased; $\mathrm{F}$ unchanged & $\mathrm{N} / \mathrm{A}$ & $\mathrm{N} / \mathrm{A}$ & $\mathrm{N} / \mathrm{A}$ \\
\hline Dose adjustment & No* & Yes & No & No \\
\hline \multicolumn{5}{|l|}{ Renal dysfunction } \\
\hline Changes & $\mathrm{CL} / \mathrm{F}$ unchanged; $\mathrm{t}_{1 / 2}$ unchanged & $t_{1 / 2}$ increased & $t_{1 / 2}$ increased & $t_{1 / 2}$ increased \\
\hline Dose adjustment & No & Yes & Yes & Yes \\
\hline \multicolumn{5}{|l|}{ Changes in elderly patients } \\
\hline Changes & $\mathrm{CL}$ unchanged; $\mathrm{t}_{1 / 2}$ unchanged; $\mathrm{F}$ increased & $\mathrm{N} / \mathrm{A}$ & $\mathrm{N} / \mathrm{A}$ & None \\
\hline Dose adjustment & No & Unknown & Unknown & No \\
\hline
\end{tabular}

CL Clearance; F Bioavailability; N/A Not available; $t_{1 / 2}$ Half-life. *For usual therapeutic dose for a limited time period in mild to moderate impairment. Data from references 10,24,29,136,137

elderly patients or those with renal or mild to moderate hepatic impairment when the drug is used at the usual therapeutic dose for a limited time (25). Larger doses used in continuous infusion dosing regimens have not been studied in these patient populations $(26,34-36,38)$.

\section{COMPARISONS WITH $\mathrm{H}_{2}$ RAs}

Pharmacology: Pantoprazole affects acid secretion at the final common pathway - the proton pump. The $\mathrm{H}_{2} \mathrm{RAs}$, on the other hand, work only to inhibit acid production mediated by histamine. They are competitive antagonists of the histamine 2 receptors. Because of the nature of competitive receptor antagonism, these agents are more likely than PPIs to be affected by downregulation and tolerance $(1,87)$.

Pharmacokinetics: Table 2 summarizes the pharmacokinetic parameters of other acid suppressive agents available in parenteral dosage forms. In comparison with the $\mathrm{H}_{2} \mathrm{RAs}$, intravenous pantoprazole has a shorter half-life but a longer duration of action because of its covalent binding to the proton pump (1). This longer duration of action allows once daily pantoprazole dosing, contrary to the $\mathrm{H}_{2} \mathrm{RAs}$, which require multiple daily doses. All $\mathrm{H}_{2} \mathrm{RAs}$ require dosing adjustments in renal impairment, and cimetidine also requires adjustment in hepatic impairment. Intravenous pantoprazole can be safely administered to patients with renal impairment $(25,34,35)$ and those with mild to moderate hepatic impairment when administered at the usual dose for a limited time $(25,36)$.

Drug interactions: Because of differences in metabolism and affinity for cytochrome P450 enzymes, pantoprazole has a much lower potential for drug interactions than other PPIs $(26,30,121)$. As discussed above, no drug interactions have been documented between pantoprazole and drugs that are representative of the most important CYP450 families. On the contrary, drug interactions with cimetidine and raniti- dine are more common (122). Caution is especially warranted when administering drugs such as warfarin, procainamide, phenytoin and theophylline.

Pharmacodynamics: Intravenous pantoprazole is a more potent acid suppressive agent than the $\mathrm{H}_{2} \mathrm{RAs}$ (13). The $\mathrm{H}_{2} \mathrm{RAs}$ are also subject to large interindividual variability (123) and may lose their effect over time because of tolerance $(87,90,124,125)$. Several clinical trials have demonstrated that increasing doses of $\mathrm{H}_{2} \mathrm{RAs}$ are required over time to maintain a specific $\mathrm{pH}$ level and/or that specific doses of $\mathrm{H}_{2} \mathrm{RAs}$ lose their efficacy over time $(87,90,124,125)$. Tolerance may develop after as little as $42 \mathrm{~h}$ of therapy (126) and has been observed in healthy volunteers (87), critically ill patients (126) and patients with gastrointestinal bleeding $(90,106)$. In contrast, the acid suppressive effects of pantoprazole and other PPIs are substantial with the initial dose (13) and increase over time (19,127-130).

Adverse effects: In general, all PPIs and $\mathrm{H}_{2} \mathrm{RA}$ are well tolerated, with an incidence of minor and serious side effects around $2.5 \%$, which is not different from that of placebo (131). However, parenteral cimetidine $(132,133)$ and ranitidine (134) may cause bradycardia, hypotension and arrhythmias. This is especially a concern with rapid intravenous injection of these agents, hence the recommendation for slow injection. In contrast, intravenous pantoprazole is well tolerated and has no significant effect on heart rate, contractility or blood pressure (135).

Dosing and administration: Intravenous pantoprazole has several dosing and administration advantages over parenteral $\mathrm{H}_{2} \mathrm{RAs}$, including once daily dosing (compared with multiple daily dosing with $\mathrm{H}_{2} \mathrm{RAs}$ ), administration of reconstituted solution without further dilution and bolus administration over $2 \mathrm{~min}$ (instead of $5 \mathrm{~min}$ or longer with $\mathrm{H}_{2} \mathrm{RAs}$ ).

\section{CONCLUSIONS}

The introduction of intravenous pantoprazole to the Cana- 
dian market provides clinicians with a useful tool for reducing acid production in the acute care setting. The agent effectively increases intragastric $\mathrm{pH}$ and has many advantages over the available parenteral $\mathrm{H}_{2}$ RAs. Although more research studies are necessary, current data indicate that it is a safe drug, without interactions mediated by the cytochrome P450 enzyme system. Its simple dosing and administration features, as well as lack of tolerance development, make it an attractive agent for inclusion on a hospital formulary.

\section{REFERENCES}

1. Sachs G. Proton pump inhibitors and acid-related diseases. Pharmacotherapy 1997; 17:22-37.

2. Chiba N. Proton pump inhibitors in acute healing and maintenance of erosive or worse esophagitis: a systematic overview. Can J Gastroenterol 1997;11(Suppl B):66-73.

3. Bardhan KD. The role of proton pump inhibitors in the treatment of gastro-oesophageal reflux disease. Aliment Pharmacol Ther 1995;9(Suppl 1):15-25.

4. Sanders SW. Pathogenesis and treatment of acid peptic disorders: comparison of proton pump inhibitors with other antiulcer agents. Clin Ther 1996;18:2-34.

5. Kromer W. Similarities and differences in the properties of substituted benzimidazoles: a comparison between pantoprazole and related compounds. Digestion 1995;56:443-54.

6. Shin JM, Besancon M, Prinz C, Simon A, Sachs G. Continuing development of acid pump inhibitors: site of action of pantoprazole. Aliment Pharmacol Ther 1994;8(Suppl 1):11-23.

7. Beil W, Staar U, Sewing KF. Pantoprazole: a novel H+/K(+)-ATPase inhibitor with an improved $\mathrm{pH}$ stability. Eur J Pharmacol 1992;218:265-71.

8. Parsons ME. Pantoprazole, a new proton-pump inhibitor, has a precise and predictable profile of activity. Eur J Gastroenterol Hepatol 1996;8(Suppl 1):15-20.

9. Shin JM, Besancon M, Simon A, Sachs G. The site of action of pantoprazole in the gastric $\mathrm{H}+/ \mathrm{K}(+)$-ATPase. Biochim Biophys Acta 1993;1148:223-33.

10. Huber R, Kohl B, Sachs G, Senn-Bilfinger J, Simon WA, Sturm E. Review article: the continuing development of proton pump inhibitors with particular reference to pantoprazole. Aliment Pharmacol Ther 1995;9:363-78.

11. Simon B, Muller P, Bliesath H, et al. Single intravenous administration of the $\mathrm{H}+, \mathrm{K}(+)$-ATPase inhibitor BY 1023/SK\&F 96022 - inhibition of pentagastrin-stimulated gastric acid secretion and pharmacokinetics in man. Aliment Pharmacol Ther 1990;4:239-45.

12. Straathof JWA, Gielkens HAJ, Wurst W, et al. Pentagastrin enhances the effect of intravenous pantoprazole. Gastroenterology 1997;112:A299. (Abst)

13. Pisegna JR, Martin P, McKeand W, Ohning G, Walsh JH, Paul J. Inhibition of pentagastrin-induced gastric acid secretion by intravenous pantoprazole: a dose-response study. Am J Gastroenterol 1999;94:2874-80.

14. Londong W. Effect of pantoprazole on 24-h intragastric $\mathrm{pH}$ and serum gastrin in humans. Aliment Pharmacol Ther 1994;8(Suppl 1):39-46.

15. Hartmann M, Ehrlich A, Fuder H, et al. Equipotent inhibition of gastric acid secretion by equal doses of oral or intravenous pantoprazole. Aliment Pharmacol Ther 1998;12:1027-32.

16. Metz DC, Pratha V, Martin P, et al. Oral and intravenous dosage forms of pantoprazole are equivalent in their ability to suppress gastric acid secretion in patients with gastroesophageal reflux disease. Am J Gastroenterol 2000;95:626-33.

17. Freston J, Taubel J, Lukasik N, Pan WJ, Chiu YL. NG lansoprazole or IV pantoprazole: which provides better $\mathrm{pH}$ control? Gastroenterology 2000;118(Suppl 2):3611. (Abst)

18. Barclay ML, Begg EJ, Robson RA, Peters WA, Ketelbey JW. Lansoprazole pharmacokinetics differ in patients with oesophagitis compared to healthy volunteers. Aliment Pharmacol Ther 1999;13:1215-9.

19. Brunner G, Luna P, Hartmann M, Wurst W. Optimizing the intragastric $\mathrm{pH}$ as a supportive therapy in upper GI bleeding. Yale J Biol Med 1996;69:225-31.

20. van Rensburg CJ, Thorpe A, Warren B, et al. Intragastric pH during pantoprazole infusion of $6 \mathrm{mg} /$ hour in patients with bleeding peptic ulceration. Gastroenterology 1999;116:A344. (Abst)

21. van Rensburg CJ, Thorpe A, Warren B, et al. Intragastric pH in patients with bleeding peptic ulceration during pantoprazole infusion of $8 \mathrm{mg} /$ hour. Gastroenterology 1997;112:A321. (Abst)

22. Pue MA, Laroche J, Meineke I, De Mey C. Pharmacokinetics of pantoprazole following single intravenous and oral administration to healthy male subjects. Eur J Clin Pharmacol 1993;44:575-8.

23. Hartmann M, Bliesath H, Huber R, Koch HJ, Steinijans VW, Wurst W. Lack of influence of antacids on the pharmacokinetics of the new gastric $\mathrm{H}+/ \mathrm{K}+$-ATPase inhibitor pantoprazole. Gastroenterology 1994;106:A91. (Abst)

24. Zech K, Steinijans VW, Huber R, Kolassa N, Radtke HW. Pharmacokinetics and drug interactions - relevant factors for the choice of a drug. Int J Clin Pharmacol Ther 1996;34(1 Suppl):3-6.

25. Benet LZ, Zech K. Pharmacokinetics - a relevant factor for the choice of a drug? Aliment Pharmacol Ther 1994;8(Suppl 1):25-32.

26. Steinijans VW, Huber R, Hartmann M, et al. Lack of pantoprazole drug interactions in man. Int J Clin Pharmacol Ther 1994;32:385-99.

27. Simon B, Muller P, Hartmann M, et al. Pentagastrin-stimulated gastric acid secretion and pharmacokinetics following single and repeated intravenous administration of the gastric $\mathrm{H}+$, K(+)-ATPase-inhibitor pantoprazole (BY1023/SK\&F96022) in healthy volunteers.

Z Gastroenterol 1990;28:443-7.

28. Tanaka M, Yamazaki H, Ryokawa Y, Hakusui H, Nakamichi N, Sekino H. Pharmacokinetics and tolerance of pantoprazole, a proton pump inhibitor after single and multiple oral doses in healthy Japanese volunteers. Int J Clin Pharmacol Ther 1996;34:415-9.

29. Bliesath H, Huber R, Hartmann M, Luhmann R, Wurst W. Dose linearity of the pharmacokinetics of the new $\mathrm{H}+/ \mathrm{K}(+)$-ATPase inhibitor pantoprazole after single intravenous administration. Int J Clin Pharmacol Ther 1994;32:44-50.

30. Huber R, Hartmann M, Bliesath H, Luhmann R, Steinijans VW, Zech K. Pharmacokinetics of pantoprazole in man. Int J Clin Pharmacol Ther 1996;34:185-94.

31. Tucker GT. The interaction of proton pump inhibitors with cytochromes P450. Aliment Pharmacol Ther 1994;8(Suppl 1):33-8.

32. Simon WA. Pantoprazole - Which cytochrome P450 isozymes are involved in its biotransformation? Gut 1995;37(Suppl 2):A135. (Abst)

33. Simon WA. Different metabolism of the proton pump inhibitors in man. Gastroenterology 1996;110:A258. (Abst)

34. Lins RL, De Clercq I, Hartmann M, et al. Pharmacokinetics of the proton pump inhibitor pantoprazole in patients with severe renal impairment. Gastroenterology 1994;106:A126. (Abst)

35. Kliem V, Bahlmann J, Hartmann M, Huber R, Luhmann R, Wurst W. Pharmacokinetics of pantoprazole in patients with end-stage renal failure. Nephrol Dial Transplant 1998;13:1189-93.

36. Brunner G, Chang J, Hartmann M, Huber R, Bliesath H, Luhmann R. Pharmakokinetik von Pantoprazol bei Patienten mit Leberzirrhose. Med Klin 1994;89(Suppl I):189.

37. Breuel HP, Horak J, Horejsova M, et al. Pantoprazole in patients with varying degree of liver impairment in comparison to healthy controls. Gastroenterology 1998;114:A6. (Abst)

38. Breuel HP, Hartmann M, Bondy S, et al. Pantoprazole in the elderly: no dose-adjustment. Gut 1994;35(Suppl 4):77. (Abst)

39. Teyssen S, Singer MV, Heinze H, et al. Pantoprazole does not influence the pharmacokinetics of ethanol in healthy volunteers. Gastroenterology 1996;110(4 Suppl):A277. (Abst)

40. De Mey C, Meineke I, Steinijans VW, et al. Pantoprazole lacks interaction with antipyrine in man, either by inhibition or induction. Int J Clin Pharmacol Ther 1994;32:98-106.

41. Gugler R, Hartmann M, Rudi J, et al. Lack of pharmacokinetic interaction of pantoprazole with diazepam in man. Br J Clin Pharmacol 1996;42:249-52.

42. Bliesath H, Huber R, Steinijans VW, Koch HJ, Wurst W, Mascher H. Lack of pharmacokinetic interaction between pantoprazole and diclofenac. Int J Clin Pharmacol Ther 1996;34:152-6.

43. Huber R, Bliesath H, Hartmann M, et al. Pantoprazole does not interact with the pharmacokinetics of carbamazepine. Int J Clin Pharmacol Ther 1998;36:521-4. 
44. Schulz HU, Hartmann M, Krupp S, et al. Pantoprazole lacks interaction with the NSAID naproxen. Gastroenterology 2000;118(Suppl 2):A1304. (Abst)

45. Ferron GM, Paul JC, Fruncillo RJ, Martin PT, Yacoub L, Mayer PR. Lack of pharmacokinetic interaction between oral pantoprazole and cisapride in healthy adults. J Clin Pharmacol 1999;39:945-50.

46. Walter-Sack IE, Bliesath $\mathrm{H}$, Stotzer F, et al. Lack of pharmacokinetic and pharmacodynamic interaction between pantoprazole and glibenclamide in humans. Clin Drug Invest 1998;15:253-60.

47. Hartmann M, Huber R, Bliesath H, et al. Lack of interaction between pantoprazole and digoxin at therapeutic doses in man. Int J Clin Pharmacol Ther 1995;33:481-5.

48. Koch HJ, Hartmann M, Bliesath H, et al. Pantoprazole has no influence on steady state pharmacokinetics and pharmacodynamics of metoprolol in healthy volunteers. Int J Clin Pharmacol Ther 1996;34:420-3.

49. Bliesath H, Huber R, Steinijans VW, Koch HJ, Kunz K, Wurst W. Pantoprazole does not interact with nifedipine in man under steady-state conditions. Int J Clin Pharmacol Ther 1996;34:51-5.

50. Lorf T, Ramadori G, Ringe B, Schworer H. Pantoprazole does not affect cyclosporin A blood concentration in kidney-transplant patients. Eur J Clin Pharmacol 2000;55:733-5.

51. Middle MV, Muller FO, Schall R, et al. No influence of pantoprazole on the pharmacokinetics of phenytoin. Int J Clin Pharmacol Ther 1995;33:304-7.

52. Hartmann M, Zech K, Bliesath H, et al. Pantoprazole lacks induction of CYP1A2 activity in man. Int J Clin Pharmacol Ther 1999;37:159-64.

53. Andersson T, Holmberg J, Rohss K, Walan A. Pharmacokinetics and effect on caffeine metabolism of the proton pump inhibitors, omeprazole, lansoprazole, and pantoprazole. Br J Clin Pharmacol 1998;45:369-75.

54. Schulz HU, Hartmann M, Steinijans VW, et al. Lack of influence of pantoprazole on the disposition kinetics of theophylline in man. Int J Clin Pharmacol Ther 1996;34(1 Suppl):51-7.

55. Pan WJ, Goldwater DR, Zhang Y, Pilmer BL, Hunt RH. Lack of a pharmacokinetic interaction between lansoprazole or pantoprazole and theophylline. Aliment Pharmacol Ther 2000;14:345-52.

56. Dilger K, Zheng Z, Klotz U. Lack of drug interaction between omeprazole, lansoprazole, pantoprazole and theophylline. Br J Clin Pharmacol 1999;48:438-44.

57. Ehrlich A, Fuder H, Hartmann M, et al. Lack of pharmacodynamic and pharmacokinetic interaction between pantoprazole and phenprocoumon in man. Eur J Clin Pharmacol 1996;51:277-81.

58. Duursema L, Muller FO, Schall R, et al. Lack of effect of pantoprazole on the pharmacodynamics and pharmacokinetics of warfarin. Br J Clin Pharmacol 1995;39:700-3.

59. Lorf T, Ramadori G, Ringe B, Schwörer $H$. The effect of pantoprazole on tacrolimus and cyclosporin A blood concentrations in transplant recipients. Eur J Clin Pharmacol 2000;56:439-40.

60. Hartmann M, Bliesath H, Maier J, et al. Pantoprazole lacks interaction with the NSAID piroxicam in man. Eur J Clin Pharmacol 2000;56:A16. (Abst)

61. Lange D, Pavao JH, Wu J, Klausner M. Effect of a cola beverage on the bioavailability of itraconazole in the presence of $\mathrm{H} 2$ blockers. J Clin Pharmacol 1997;37:535-40.

62. Blum RA, D'Andrea DT, Florentino BM, et al. Increased gastric pH and the bioavailability of fluconazole and ketoconazole. Ann Intern Med 1991;114:755-7.

63. Janssen-Ortho Inc. Sporanox capsules. In: Gillis MC, ed. Compendium of Pharmaceuticals and Specialties. Ottawa: Canadian Pharmacists Association, 1999:1681-3.

64. Van Der Meer JW, Keuning JJ, Scheijgrong HW, Heykants J, Van Cutsen J, Brugmans J. The influence of gastric acidity on the bioavailability of ketoconazole. J Antimicrob Chemother 1980;6:552-4.

65. Jaruratanasirikul S, Sriwiriyajan S. Effect of omeprazole on the pharmacokinetics of itraconazole. Eur J Clin Pharmacol 1998;54:159-61.

66. Drew RH, Perfect JR, Gallis HA. Use of fluconazole in a patient with documented malabsorption of ketoconazole. Clin Pharm 1988;7:622-3.

67. Chin TW, Loeb M, Fong IW. Effects of an acidic beverage (Coca-Cola) on absorption of ketoconazole. Antimicrob Agents Chemother 1995;39:1671-5.
68. Jaruratanasirikul S, Kleepkaew A. Influence of an acidic beverage (Coca-Cola) on the absorption of itraconazole. Eur J Clin Pharmacol 1997;52:235-7.

69. Fumagalli I, Klein M, Fischer R. Comparison of intravenous with oral pantoprazole in symptom relief and healing of reflux esophagitis. Gastroenterology 1998;114:A126. (Abst)

70. Plein K, Schneider A, Fischer R, Hotz J. [Efficacy and safety of sequential intravenous and oral treatment of pantoprazole in reflux esophagitis]. Leber Magen Darm 2000;30:164-8.

71. Wurzer H, Schutze K, Bethke T, Fischer R, Luhmann R, Riesenhuber C. Efficacy and safety of pantoprazole in patients with gastroesophageal reflux disease using an intravenous-oral regimen. Austrian Intravenous Pantoprazole Study Group. Hepatogastroenterology 1999;46:1809-15.

72. Paul J, Metz D, Maton P, Pisegna J, Pratha V, Martin P. Pantoprazole IV treatment decreases antacid usage in patients with gastroesophageal reflux disease. Gastroenterology 1999;116:A283. (Abst)

73. Panos MZ, Walt RP. Current management of bleeding peptic ulcer. A review. Drugs 1993;46:269-80.

74. Gilbert DA. Epidemiology of upper gastrointestinal bleeding. Gastrointest Endosc 1990;36:8-13.

75. Daneshmend TK, Hawkey CJ, Langman MJ, Logan RF, Long RG, Walt RP. Omeprazole versus placebo for acute upper gastrointestinal bleeding: randomised double blind controlled trial. BMJ 1992;304:143-7.

76. Katschinski B, Logan R, Davies J, Faulkner G, Pearson J, Langman M. Prognostic factors in upper gastrointestinal bleeding. Dig Dis Sci 1994:39:706-12.

77. Vreeburg EM, Ramnath A, Snel P, et al. Follow-up of bleeding gastroduodenal ulcers. Gastroenterology 1996;110:A288. (Abst)

78. Hochain P, Capet C, Merle V, Michel P, Riachi G, Ducrottea P. Bleeding peptic ulcer (BPU) in patients aged over 80 years: incidence and prognosis. Gut 1995;37(Suppl 2):A47. (Abst)

79. Saltzman JR, Zawacki JK. Therapy for bleeding peptic ulcers. N Engl J Med 1997;336:1091-3.

80. Fullarton GM, Macdonald AM, Mann SG, McColl KE. Controlled study of the effects of intravenous famotidine on intragastric $\mathrm{pH}$ in bleeding peptic ulcers. Aliment Pharmacol Ther 1991;5:77-84.

81. Green FW, Kaplan MM, Curtis LE, Levine PH. Effect of acid and pepsin on blood coagulation and platelet aggregation. A possible contributor to prolonged gastroduodenal mucosal hemorrhage. Gastroenterology 1978;74:38-43.

82. Patchett SE, Enright H, Afdhal N, O'Connell W, O'Donoghue DP. Clot lysis by gastric juice: an in vitro study. Gut 1989;30:1704-7.

83. Collen MJ, Kalloo AN, Sheridan MJ. Bleeding duodenal ulcer. Role of gastric acid hypersecretion. Dig Dis Sci 1993;38:269-75.

84. Collins R, Langman M. Treatment with histamine $\mathrm{H} 2$ antagonists in acute upper gastrointestinal hemorrhage. Implications of randomized trials. N Engl J Med 1985;313:660-6.

85. Walt RP, Cottrell J, Mann SG, Freemantle NP, Langman MJ. Continuous intravenous famotidine for haemorrhage from peptic ulcer. Lancet 1992;340:1058-62.

86. Brunner G, Luna P, Thiesemann C. Drugs for $\mathrm{pH}$ control in upper gastrointestinal bleeding. Aliment Pharmacol Ther 1995;9(Suppl 1):47-50.

87. Merki HS, Wilder-Smith CH. Do continuous infusions of omeprazole and ranitidine retain their effect with prolonged dosing? Gastroenterology 1994;106:60-4.

88. Kiilerich S, Rannem T, Elsborg L. Effect of intravenous infusion of omeprazole and ranitidine on twenty-four-hour intragastric $\mathrm{pH}$ in patients with a history of duodenal ulcer. Digestion 1995;56:25-30.

89. Brunner $G$, Chang J. Intravenous therapy with high doses of ranitidine and omeprazole in critically ill patients with bleeding peptic ulcerations of the upper intestinal tract: an open randomized controlled trial. Digestion 1990;45:217-25.

90. Labenz J, Peitz U, Leusing C, Tillenburg B, Blum AL, Borsch G. Efficacy of primed infusions with high dose ranitidine and omeprazole to maintain high intragastric $\mathrm{pH}$ in patients with peptic ulcer bleeding: a prospective randomised controlled study. Gut 1997;40:36-41.

91. Sanders SW, Buchi KN, Moore JG, Bishop AL. Pharmacodynamics of intravenous ranitidine after bolus and continuous infusion in patients with healed duodenal ulcers. Clin Pharmacol Ther 1989;46:545-51.

92. Lanas A, Artal A, Blas JM, Arroyo MT, Lopez-Zaborras J, Sainz R. 
Effect of parenteral omeprazole and ranitidine on gastric $\mathrm{pH}$ and the outcome of bleeding peptic ulcer. J Clin Gastroenterol 1995;21:103-6.

93. Desprez D, Blanc P, Bories JM, et al. Acute upper gastrointestinal hemorrhage: preliminary report of a randomized controlled trial comparing intravenous administration of ranitidine and omeprazole. Gastroenterology 1995;108(4 Suppl):A82. (Abst)

94. Khuroo MS, Yattoo GN, Javid G, et al. A comparison of omeprazole and placebo for bleeding peptic ulcer. N Engl J Med 1997;336:1054-8.

95. Villanueva C, Balanzo J, Torras X, et al. Omeprazole versus ranitidine as adjunct therapy to endoscopic injection in actively bleeding ulcers: a prospective and randomized study. Endoscopy 1995;27:308-12.

96. Lin HJ, Lo WC, Lee FY, Perng CL, Tseng GY. A prospective randomized comparative trial showing that omeprazole prevents rebleeding in patients with bleeding peptic ulcer after successful endoscopic therapy. Arch Intern Med 1998;158:54-8.

97. Prassler R, Hendrich H, Barnert J, Richter G, Fleischmann R, Wienbeck M. [Do proton pump inhibitors after endoscopic control of acute ulcer hemorrhage have an advantage over $\mathrm{H} 2$ receptor antagonists?]. Z Gastroenterol 1995;33:431-4.

98. Hasselgren G, Lind T, Lundell L, et al. Continuous intravenous infusion of omeprazole in elderly patients with peptic ulcer bleeding. Results of a placebo-controlled multicenter study. Scand J Gastroenterol 1997:32:328-33.

99. Schaffalitzky DM, Havelund T, Harling H, et al. Effect of omeprazole on the outcome of endoscopically treated bleeding peptic ulcers. Randomized double-blind placebo-controlled multicentre study. Scand J Gastroenterol 1997;32:320-7.

100. Li Y, Sha W, Nie Y, et al. Effect of intragastric $\mathrm{pH}$ on control of peptic ulcer bleeding. J Gastroenterol Hepatol 2000;15:148-54.

101. Peterson WL, Cook DJ. Antisecretory therapy for bleeding peptic ulcer. JAMA 1998;280:877-8.

102. Bustamante M, Stollman N. The efficacy of proton-pump inhibitors in acute ulcer bleeding: a qualitative review. J Clin Gastroenterol 1999;30:7-13.

103. Barkun AN, Cockeram AW, Plourde V, Fedorak RN. Review article: acid suppression in non-variceal acute upper gastrointestinal bleeding. Aliment Pharmacol Ther 1999;13:1565-84.

104. Sheppard DG, Fardy JM. A meta-analysis of proton pump inhibitors on rebleeding and mortality from acute upper gastrointestinal bleeding from peptic ulcer. Can J Gastroenterol 1999;13(Suppl B):155B.

105. Barnert J, Bittinger M, Wienbeck M. Effects of intravenous infusion of high dose omeprazole and ranitidine on intragastric acidity in bleeding peptic ulcer patients. Gastroenterology 1994;106:A47. (Abst)

106. Kohler B, Benz C, Maier M, Knobloch M, Riemann JF. Gastric pH monitoring in patients with acute ulcer bleeding under continuous intravenous therapy with omeprazole $(\mathrm{OM})$ or ranitidine (RAN). Gastroenterology 1994;106:A109. (Abst)

107. Schonekas H, Ahrens H, Ell C, et al. Comparison of two doses of intravenous pantoprazole in peptic ulcer bleeding. Gastroenterology 1999;106:A305. (Abst)

108. Fried R, Beglinger C, Meier R, et al. Comparison of intravenous pantoprazole with intravenous ranitidine in peptic ulcer bleeding. Gut 1999;45(Suppl V):A100. (Abst)

109. Hirschowitz BI. Zollinger-Ellison syndrome: pathogenesis, diagnosis, and management. Am J Gastroenterol 1997;92(4 Suppl):44-8.

110. Maton PN. Zollinger-Ellison syndrome. Recognition and management of acid hypersecretion. Drugs 1996;52:33-44.

111. Fraker DL, Norton JA, Saeed ZA, Maton PN, Gardner JD, Jensen RT. A prospective study of perioperative and postoperative control of acid hypersecretion in patients with Zollinger-Ellison syndrome undergoing gastrinoma resection. Surgery 1988;104:1054-63.

112. Saeed ZA, Norton JA, Frank WO, et al. Parenteral antisecretory drug therapy in patients with Zollinger-Ellison syndrome. Gastroenterology 1989;96:1393-402.

113. Vinayek R, Amantea MA, Maton PN, Frucht H, Gardner JD, Jensen RT. Pharmacokinetics of oral and intravenous omeprazole in patients with the Zollinger-Ellison syndrome. Gastroenterology 1991;101:138-47.

114. Vinayek R, Frucht H, London JF, et al. Intravenous omeprazole in patients with Zollinger-Ellison syndrome undergoing surgery.
Gastroenterology 1990;99:10-6. (published erratum appears in Gastroenterology 1990;99:905)

115. Radebold K, Bornman PC, van Wyk MEC, Kaye P, Marks IN, Terblanche J. Preliminary results of the proton-pump inhibitor pantoprazole in patients with Zollinger-Ellison syndrome. Gastroenterology 1997;112:A37. (Abst)

116. Metz DC, Forsmark CE, Soffer E, Bochenek WJ, Pisegna JR. Oral pantoprazole (Panto) effectively maintains control of acid output (AO) in Zollinger-Ellison syndrome (ZES) and idiopathic hypersecretion (IH). Gastroenterology 2000;118:A1275. (Abst)

117. Poitras P. Management of Zollinger-Ellison (ZR) patients with pantoprazole. Gastroenterology 2000;118(Suppl 2):A297. (Abst)

118. Lew EA, Pisegna JR, Starr JA, et al. Intravenous pantoprazole rapidly controls gastric acid hypersecretion in patients with Zollinger-Ellison syndrome. Gastroenterology 2000;118:696-704.

119. Metz DC, Forsmark CE, Soffer E, Bochenek W, Pisegna JR. Zollinger-Ellison syndrome patients can replace oral proton pump inhibitors with intravenous pantoprazole without losing control of acid output. Gastroenterology 1999;116:A252. (Abst)

120. Bosseckert H, Sander P, Braun W. Tolerability and efficacy of intravenous administration of pantoprazole in routine clinical practice. Clin Drug Invest 2000;19:103-9.

121. Simon WA, Budingen C, Fahr S, Kinder B, Koske M. The H+, $\mathrm{K}(+)$-ATPase inhibitor pantoprazole (BY1023/SK\&F96022) interacts less with cytochrome P450 than omeprazole and lansoprazole. Biochem Pharmacol 1991;42:347-55.

122. Smith SR, Kendall MJ. Ranitidine versus cimetidine. A comparison of their potential to cause clinically important drug interactions. Clin Pharmacokinet 1988;15:44-56.

123. Heim J, Kaufmann DNJ, Mappes A, et al. Individual responses to intravenous $\mathrm{H} 2$ receptor antagonists are unpredictable. Gastroenterology 1988;94:A180. (Abst)

124. Albin M, Friedlos J, Hillman K. Continuous intragastric $\mathrm{pH}$ measurement in the critically ill and treatment with parenteral ranitidine. Intensive Care Med 1985;11:295-9.

125. Merki HS, Halter F, Wilder-Smith CH. Diurnal secretory patterns and tolerance during individually titrated infusions of ranitidine. Gastroenterology 1993;105:748-54.

126. Geus WP, de Haas JAM, Smith SJ, et al. Evaluation of antisecretory effects of intravenous ranitidine and omeprazole in postoperative ICU patients during prolonged dosing. Gastroenterology 1997;112:A125. (Abst)

127. Cederberg C, Thomson AB, Mahachai V, et al. Effect of intravenous and oral omeprazole on 24-hour intragastric acidity in duodenal ulcer patients. Gastroenterology 1992;103:913-8.

128. Cederberg C, Rohss K, Lundborg P, Olbe L. Effect of once daily intravenous and oral omeprazole on 24-hour intragastric acidity in healthy subjects. Scand J Gastroenterol 1993;28:179-84.

129. Cederberg C, Lind T, Rohss K, Olbe L. Comparison of once-daily intravenous and oral omeprazole on pentagastrin-stimulated acid secretion in duodenal ulcer patients. Digestion 1992;53:171-8.

130. Netzer P, Gaia C, Huluk TH, et al. Effect or repeated bolus injection vs continuous infusion of high dose omeprazole and ranitidine on intragastric $\mathrm{pH}$ for 72 hours. Gastroenterology 1997;112(4 Suppl):A233. (Abst)

131. Arnold R. Safety of proton pump inhibitors - an overview. Aliment Pharmacol Ther 1994;8(Suppl 1):65-70.

132. Omote K, Namiki A, Nishikawa T, Hagiwara T, Iwasaki H, Tsuchida $\mathrm{H}$. Haemodynamic effects of famotidine and cimetidine in critically ill patients. Acta Anaesthesiol Scand 1990;34:576-8.

133. SmithKline Beecham. Tagamet. In: Gillis MC, ed. Compendium of Pharmaceuticals and Specialties. Ottawa: Canadian Pharmacists Association, 1999:1737-8.

134. Glaxo Wellcome. Zantac. In: Gillis MC, ed. Compendium of Pharmaceuticals and Specialties. Ottawa: Canadian Pharmacists Association, 1999:2006-8.

135. Bliesath H, Hartmann M, Huber R, Luehmann R, Wurst W. Lack of influence of pantoprazole on cardiovascular function in healthy volunteers: a double-blind, randomised, placebo-controlled crossover study. Clin Drug Invest 1995;9:72-8.

136. Skoutakis VA. Comparison of the parenteral histamine2-receptor antagonists. DICP 1989;23(10 Suppl):17-22.

137. Feldman M, Burton ME. Histamine2-receptor antagonists. Standard therapy for acid-peptic diseases. (Part 1 of 2). N Engl J Med 1990;323:1672-80. 


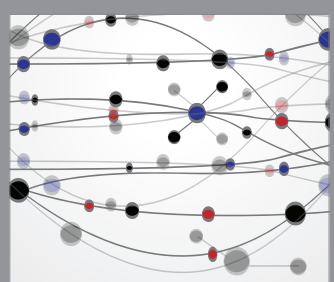

The Scientific World Journal
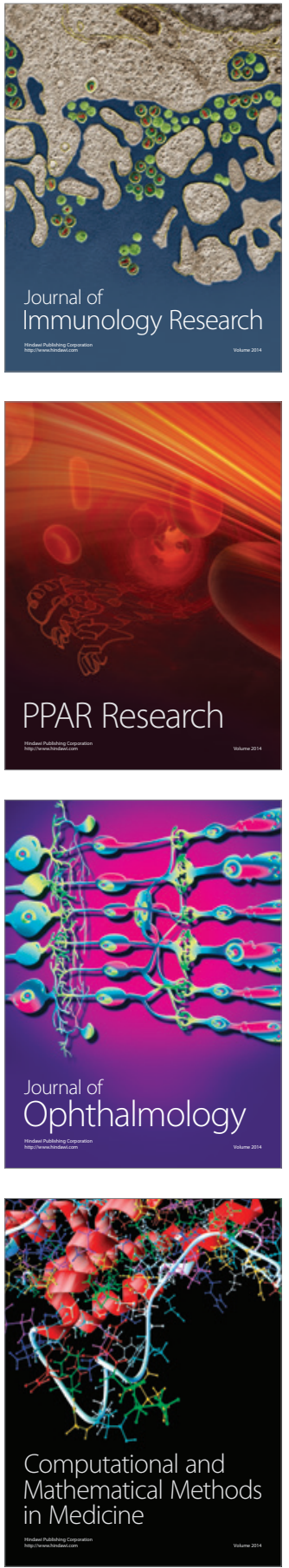

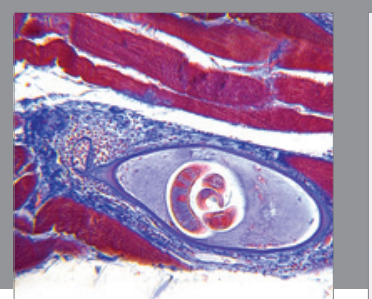

Gastroenterology Research and Practice

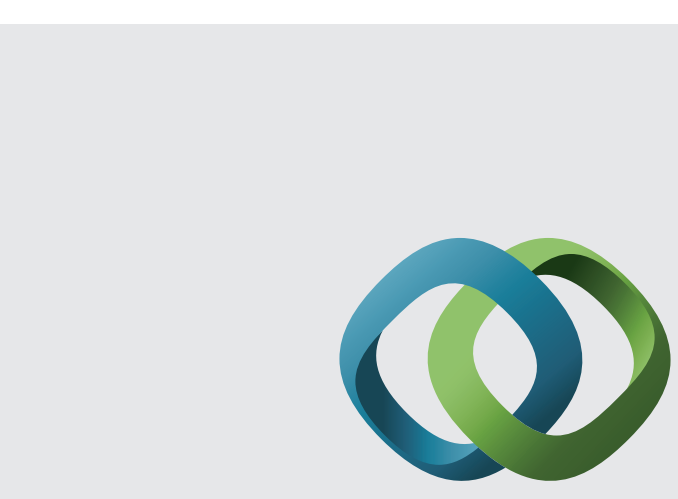

\section{Hindawi}

Submit your manuscripts at

http://www.hindawi.com
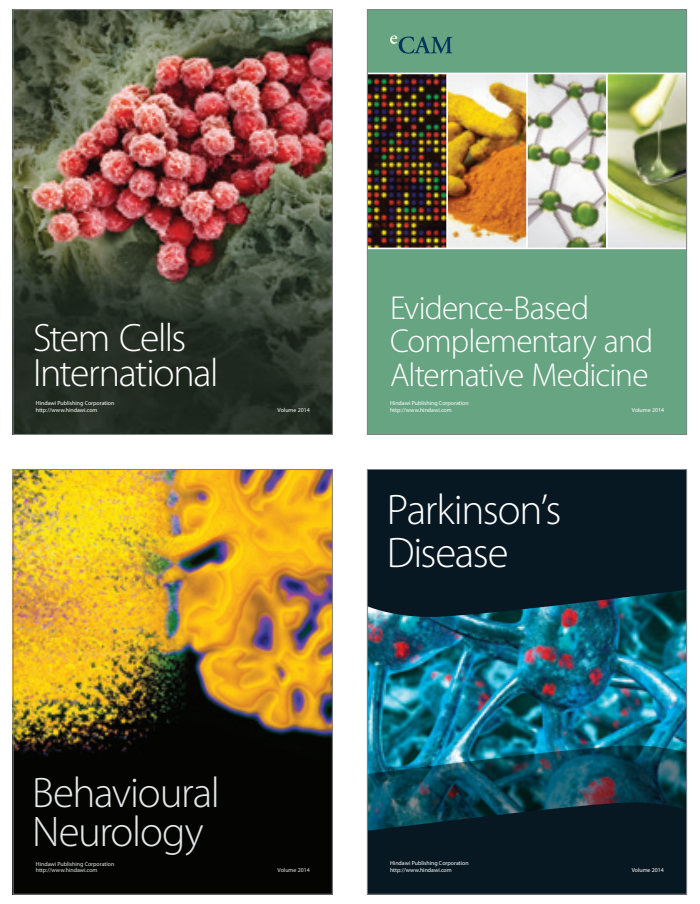
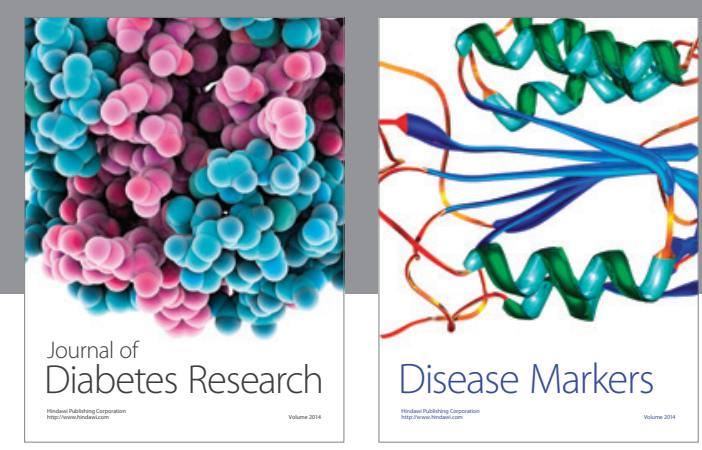

Disease Markers
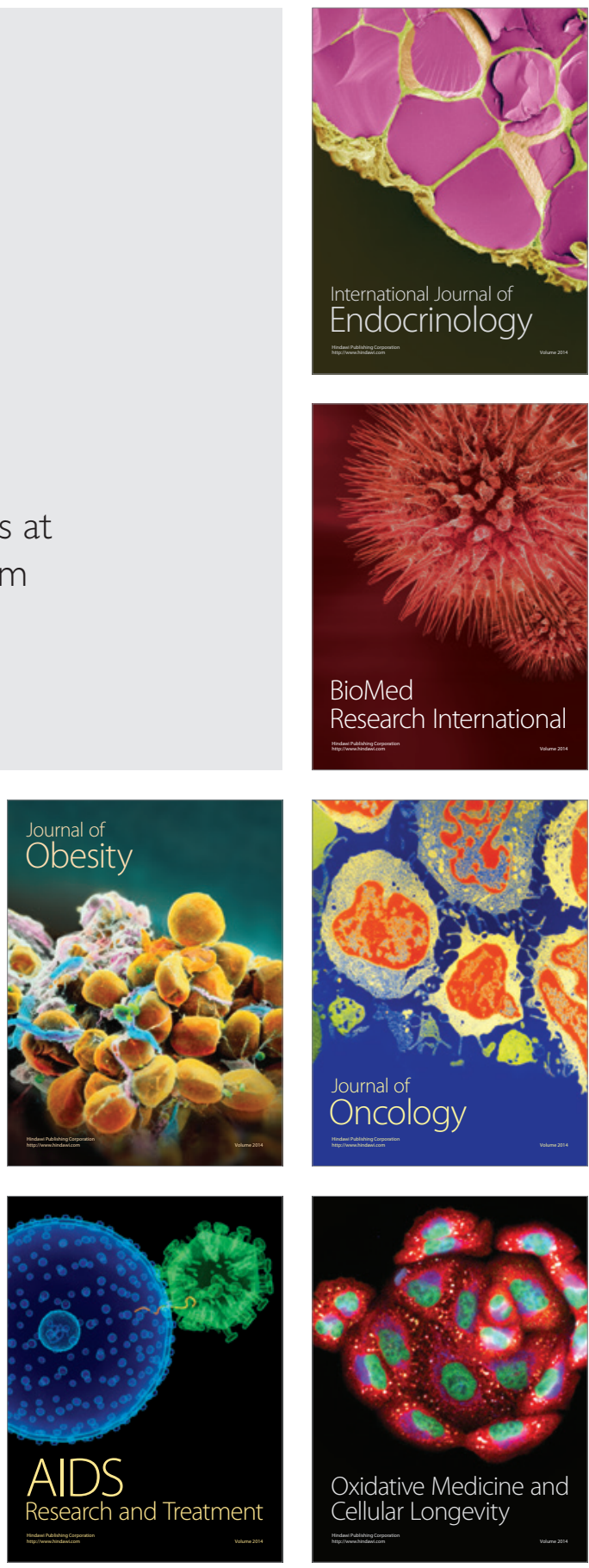